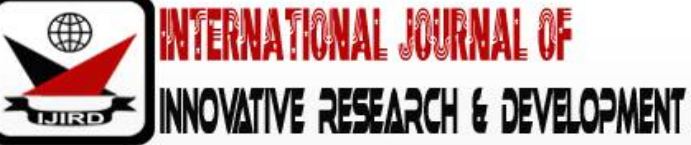

ISSN 2278 - 0211 (Online)

\section{Factors behind Female Students' Low Performance in English Language Classroom of Ambo Secondary School: Grade 9 in Focus, Ethiopia}

\author{
Yezabwork Merga \\ Lecturer, Department of English Language and Literature, Ambo University, Ethiopia
}

\begin{abstract}
:
This study focuses on factors behind female students' low participation in English classrooms with special reference to Ambo secondary school of grade 9 in the year 2017. The main objective of this study is to investigate the factors that affect female students' participation in English classrooms and then to give some suggestions that enable these groups to improve their participation in English language classrooms. The methodology that the researcher used to conduct a research was questionnaires and observation. To conduct the study, data was collected from students and teachers of grade 9 at Ambo secondary school. Concerning the students, 450 total female students of grade 9, 120 students were selected using simple random sampling technique. Similarly, all 18 teachers were involved using availability sampling technique. The data were analyzed and interpreted in terms of percentage. It was concluded that different factors like self concept, parents attitude towards women education, teachers attitude towards their female students, expectation from boys and afraid of being criticized by other students and others limited students' participation in English classroom. The researcher also recommended suggestions for the removal or minimization of those factors.
\end{abstract}

Keywords: Motivation, performance, participation

\section{Background of the Study}

Language is one of the unique possessions of human beings. It is one of the most important tools that we have as a means of communication. It is also the main facilitating instrument in education. According to Association for Development in Africa (2005) "Language is not everything in education, but without language, everything is nothing in education". Furthermore, Roll-Campbell and Qorro (1997) asserted that education is carried out largely through the medium of language. To strengthen this idea, Malekela (2003) said, "Language plays a crucial role in learning, and if the learner is handicapped in the language of instruction, then learning may not take place at all as teacher and the learner will not be communicating".

Nowadays, English is the language of the world and it plays a great role in the development of science and technology. Its contribution in the education system of many countries in the world is also paramount. The major goal of all English language teaching should be to give learners the ability to use English effectively and accurately in communication (Davies and Pears, 2000). It is believed that when students are engaged in the classrooms with their teachers or peers, they are compelled to be in the 'negotiating of meaning', that is to express and clarify their intentions, thoughts and opinions (Lightbown \& Spada, 2006).

In most of the regions in Ethiopia, English language is taught as a subject from grade one and is a medium of instruction from grade nine onward. Although English has such status in Ethiopia, students' participation in the country in general and that of female students' participation in particular using the language and their proficiency remains questionable. They hardly use English when they attend most English lessons. Rather, they tend to use local languages to reflect for they are not proficient in English language (Amlaku, 2010).

\subsection{Statement of the Problem}

The societal expectation and personal experience of female students at school has some impact on the level of confidence they develop and what they want to be. In life, participation plays a great role among people themselves in order to get better information and do any activity. When we compare participation of female students with their male counter parts in English language classroom lessons, female students are less participants. This condition may lead to lack of attentiveness that encourages female students to be silent, shy and passive.

Access to school by itself is not enough, and it needs attending the courses actively and performing successfully. From personal experience and observation when the researcher was high school teacher, she observed that many high school female students do not have adequate language ability to communicate effectively with their teachers. Poor English language command has become an impediment for their success in their learning experiences. This incompetency of 
students will obviously be reflected in their participation while they are learning. Students get very limited exposure, although proficiency of the language is paramount.

\subsection{Objective of the Study}

The main objective of this study is to investigate the factors for female students' low participation in English language classrooms.

\subsection{Significance of the Study}

The study can serve as valuable information for concerned agencies; policy makers, service providers, schools and other related institutions. It can also serve as a spring board for others who want to conduct further research in this area.

\subsection{Scope of the Study}

The study is limited to Ambo Secondary School and mainly based on the analysis of female students' participation in English classroom with particular emphasis on grade 9 female students of the year 2017 at Ambo secondary school. The total numbers of grade nine female students were about 450 in Ambo Secondary school in the mentioned year. The researcher took 120 female students as participants of the research considering homogeneity and other factors into account.

\section{Review of Related Literature}

Participation refers to the observable act of involvement in lesson or academic task. It is also response given by the students with the institution of the teacher that gives the chance to respond. No one can deny that active classroom participation plays an important role in the success of language learning (Tatar, 2005). Participation through training, question and answering, group discussion and forwarding question is the most important way for one to learn, be improved and be knowledgeable person. Similarly, the importance of learner participation is further stressed by Jackson (2002) who contends that participation provides opportunity to construct and shape one's own identity as member of the classroom. The linkage between classroom participation and students' academic achievement is undeniable. A study by Liu (2005) also finds that students who participate actively tend to have better academic achievement when they are compared to students who do not participate. Furthermore, it is a common belief that participation in verbal interaction offers language learners the opportunity to follow up on new words and structures to which they have been exposed during language lessons and to practice them in context (Liu, 2005).

Classroom participation involves a variety of activities and has different forms like students' simple questions and explanations (Cornelius, R \& Gray, J. 1988). According to Wade (1994), ideal class discussions require participation, interest, learning of all the students and absorbing others' explanations and information. Vuzo (2010) reported that "It is through interactions with each other that teachers and students work together to create intellectual and practical activities that shape both the form and the content of the target subject. Furthermore, according to (Yusuf 2007), quality of classroom participation was influenced by teachers' competence in class management; teachers' questioning strategy, and students' self-confidence and their vocabulary mastery.

Motivation is another important factor that influences success or failure in learning language, particularly a second language or foreign language (Gardner, 2006). It is a factor that strongly affects everything people do in their lives. Motivated students show more effort and determination to reach their goals, which also directly increased their scores whereas students who show less effort perform less to achieve their goals.

Education is the major instrument for economic and social development of a society. Education also contributes to socioeconomic development by endowing individuals with the means of improving their health, skills, knowledge and capacity for productive work. An educated female is likely to become: a more competent and knowledgeable mother, a more productive and better paid worker, an informed citizen, a self-confident individual and a skilled decision maker (Tadesse, 2009). Since females are the integral part of the society, the significance of their education has been demonstrated in the betterment of human lives and in the enhancements of scientific and technological changes (Woldu, 1999).

There are several factors that affect females' education. Among others: self-concept, expectation from boys and afraid of being criticized by other students, parents' attitude towards women education and teachers' attitude towards female students.

Self-concept is an individual's perception towards oneself and one can understand herself/ himself negatively or positively. Many people have argued that negative self-concept might particularly be revealed among children who have experienced discrimination or economic privation, and this might explain why these groups do less in school than others (Purlieus Ann, 1978). This means that discrimination is one cause of negative self-concept. In most part of the society, female students are discriminated and considered as a weaker and incompetent, even if they are surviving with the rest part of the world at large and their society in particular engaging themselves in different tasks.

Expectation from boys and afraid of being criticized by other students are the other reasons that affect female students' classroom participation. "...when questions are raised from teacher, I want to answer those questions but there is the issue in the class that girls should keep quite..." David Maraud (2006). Due to this reason and others, most of the time, female students prefer silence to actively participating even in their classroom. As it is simple to guess, the end result may be expectation from others as a result of the fear that they develop instead of avoiding it.

Asfaw and Menna (1987) defined parents' attitude in a very condensed way as follows, 'Parents assume boys education has high economic return than their counter parts. According to these scholars, parents prefer to educate boys. More importantly, the parents are influenced by the attitudes and values towards male and female education. From this 
unhealthy and unscientific outlook, women develop image of themselves as women are inferior to men and that they are there neither to be seen nor to be heard'.

The other social factor that hinders girls' participation in education is teachers' attitude towards female students. As it is known, teachers are the most important agents in school to shape and mold the habits, manner and attitude of students particularly in teaching and learning process. One of the most basic by the teacher and for the teacher to put for their positive expectations in order to motivate the student to learn principles of teaching abilities is supporting of the student (Yavuzer, 2000). Even if learners should have to get equal chance to participate in the classroom, sometimes some teachers prefer male students to perform different activities in their classrooms to female students. This attitude may lead female students to lose effort and perform less to be engaged in their overall activities since participation needs more practice to be nearer to perfection.

\section{Research Design and Methodology}

The research was both qualitative and quantitative in nature. This study was mainly designed to investigate the major factors of female students' low participation in English classroom of grade nine. The objective was to provide indepth analysis and report problems of female learners' participation of English language classroom and to seek the possibility and improve the current situation of English language so as to minimize the problems of female students for their continued progress.

The research focuses on investigating the problems of female students' participation of grade nine students in Ambo secondary school. Of the total number of students, 120 were chosen using simple random sampling technique. As far as teachers are concerned, all grade nine teachers which were 18 in number were involved in the study using availability sampling technique. The data were gathered using questionnaire and observation as instrument of data collection.

Questionnaire as instrument of data collection has been used to collect information from both students and teachers. The researcher also used observation in order to analyze and find out the degree of female students' participation in English classrooms while the actual teaching learning processes were taking place. In fact, two classes have been randomly considered for observation using observation checklist. The data gathered via questionnaire were analyzed by using percentage and presented in table form. Similarly, the information that the researcher gets through observation to crosscheck and supplement the information gathered through the questionnaire was analyzed through summary depending on the observation check list result in order to get rich data about the research.

\section{Discussion and Analysis}

In this part of the research, data has been discussed and analyzed thoroughly. Here under, the data obtained from students have been discussed in table one to six and data obtained from teachers in table seven to nine are presented.

\begin{tabular}{|c|c|c|c|}
\hline & Number of Respondents & In Number & In Percentage (\%) \\
\hline \multirow{3}{*}{ Age } & Below 16 & 18 & $15 \%$ \\
\cline { 2 - 4 } & $16-18$ & 90 & $75 \%$ \\
\cline { 2 - 4 } & $18-19$ & 12 & $10 \%$ \\
\cline { 2 - 4 } & Total & 120 & $100 \%$ \\
\hline
\end{tabular}

Table 1: Age, Sex and Grade of the Sample Students

As it is indicated in table 1, 18 (15\%) of the sample respondents are below 16 years old. Similarly, majority of i.e. $90(75 \%)$ of the respondents are between the age of 16 and 18 . The remaining sample students i.e. $12(10 \%)$ of them are between the age of 18-19. Regarding the sex of the sample respondents, all of them are female.

\begin{tabular}{|c|c|c|c|c|}
\hline No & Item & Alternative & No of respondents & In percentage (\%) \\
\hline \multirow[t]{3}{*}{1.} & \multirow{3}{*}{$\begin{array}{c}\text { Do your English teachers } \\
\text { encourage and motivate you on } \\
\text { participation? }\end{array}$} & Yes & 24 & $20 \%$ \\
\hline & & No & 96 & $80 \%$ \\
\hline & & Total & 120 & $100 \%$ \\
\hline \multirow[t]{3}{*}{2.} & \multirow{3}{*}{$\begin{array}{c}\text { Do you have interest to learn } \\
\text { English? }\end{array}$} & Yes & 108 & $90 \%$ \\
\hline & & No & 12 & $10 \%$ \\
\hline & & Total & 120 & $100 \%$ \\
\hline
\end{tabular}

Table 2: Students' Response on Girls' Participation and Attitude towards English Subject

From the above table 2, 24 (20\%) of the students replied that their English teachers encourage them to participate in English class whereas majority of the respondents i.e. 96 (80\%) of female students did not get this chance. From the result, it is possible to conclude that majority of English teachers did not motivate female students to learn English subject. As the same table indicates 108 (90\%) of the sample female students have interest to learn English whereas only $12(10 \%)$ of the sample female students do not have. This data show that grade 9 female students have high interest to learn English lesson although they lack encouragement from their teachers. 


\begin{tabular}{|c|c|c|c|c|}
\hline No & Item & Alternative & No Of Respondents & In Percentage (\%) ) \\
\hline \multirow{2}{*}{3.} & Do you tell your problems to & Yes & 45 & $37 \%$ \\
\cline { 3 - 4 } & your teachers? & No & 75 & $63 \%$ \\
\cline { 3 - 4 } & & Total & 120 & $100 \%$ \\
\hline
\end{tabular}

Table 3: Students' Response on Telling Their Problems for Their Teachers

As it is indicated in table 3, 45 (37\%) of female students responded that whenever they encountered problems they tell to their teachers. But, majority of the respondents i.e. 75 (63\%) of them do not tell the problems they face to their teachers. Had students communicated their problems to teachers, they would get advice and counseling from their teachers which can be considered as one of the determining factors in enhancing female students' participation in English language classrooms.

\begin{tabular}{|c|c|c|c|c|}
\hline No & Item & & No of Respondents & In Percentage (\%) \\
\hline \multirow[t]{4}{*}{4.} & \multirow{4}{*}{$\begin{array}{l}\text { How do you see the rate of } \\
\text { female students' } \\
\text { participation within your } \\
\text { class? }\end{array}$} & Good & 5 & $4.17 \%$ \\
\hline & & Medium & 15 & $12.5 \%$ \\
\hline & & Poor & 100 & $83.33 \%$ \\
\hline & & Total & 120 & $100 \%$ \\
\hline \multirow[t]{4}{*}{5.} & \multirow{4}{*}{$\begin{array}{c}\text { What is the importance of } \\
\text { participating girls in } \\
\text { education? }\end{array}$} & $\begin{array}{c}\text { To improve life of } \\
\text { society }\end{array}$ & 18 & $15 \%$ \\
\hline & & To improve their life & 30 & $25 \%$ \\
\hline & & Both & 72 & $60 \%$ \\
\hline & & Total & 120 & $100 \%$ \\
\hline
\end{tabular}

Table 4: Students' Response on the Rate and Importance of Girls' Participation

As it is indicated in table 4 of question number 4 , only $5(12.5 \%)$ of female students replied that rate of participation of female students is good; whereas, significant of them i.e. 15 (12.5\%) of them said that females' student's participation is medium. Majority of the respondents means more than half of them i.e. $100(83.33 \%)$ replied that they rate female students' participation is poor in their respective classes. This shows that majority of female students' participation in English classrooms at Ambo secondary school is poor.

As it is also indicated in table 4 of question number 5, 18 (15\%) of the respondents said that the participation of female students is important to improve the life of the society, whereas 30 (25\%) of female student respondents replied that the participation of female students is important to improve their life. On the other hand, majority of female respondents i.e. $72(60 \%)$ of the respondents said that the participation of female students is important to improve both the life of the society and their own life. Based on the finding, it is possible to conclude that most of the respondents' believed that participation is important for both the betterment of female students' life and that of their society.

\begin{tabular}{|c|c|c|c|c|}
\hline No & Item & Alternative & No of Respondents & In percentage (\%) \\
\hline 6. & \multirow{2}{*}{$\begin{array}{c}\text { How often do your English } \\
\text { teachers encourage you to }\end{array}$} & Always & 6 & $5 \%$ \\
\cline { 3 - 5 } & participate in the classroom? & Sometimes & 24 & $20 \%$ \\
\cline { 3 - 5 } & & Rarely & 90 & $75 \%$ \\
\cline { 3 - 5 } & & Total & 120 & $100 \%$ \\
\hline
\end{tabular}

Table 5: Students' Response on How often English Teachers Encourage Girls' Participation

As it is shown in table 5, 6 (5\%) of female students responded that their English teachers always encourage them to participate in their classroom, whereas $24(20 \%)$ of female students replied that their English teachers sometimes encourage their participation in their classroom. But, majority of them i.e. $90(75 \%)$ of female students responded that their English teachers rarely encourage female students' participation in their classes. What can be concluded here are that majority of English teachers is not encouraging their female students' participation in their classroom which adversely affects motivation and performance of female students.

\begin{tabular}{|c|c|c|c|c|}
\hline No & Item & Alternative & No of respondents & In percentage (\%) \\
\hline \multirow[t]{3}{*}{7.} & \multirow{3}{*}{$\begin{array}{c}\text { Do you expect that girls } \\
\text { should be active participants } \\
\text { in their classroom? }\end{array}$} & Yes & 30 & $25 \%$ \\
\hline & & No & 90 & $75 \%$ \\
\hline & & Total & 120 & $100 \%$ \\
\hline \multirow[t]{3}{*}{8.} & \multirow{3}{*}{$\begin{array}{l}\text { Does family occupation affect } \\
\text { girls' participation in the } \\
\text { school? }\end{array}$} & Yes & 81 & $67.5 \%$ \\
\hline & & No & 39 & $32.5 \%$ \\
\hline & & Total & 120 & $100 \%$ \\
\hline
\end{tabular}

Table 6: Students' Response on the Expectation and Family Occupation That Affect Girls' Participation 
As it is indicated in table 6 of question number 2, 30 (25\%) of female student respondents expect girls' to be active participants in the classroom; whereas the majority i.e. 90 (75\%) of the sample students responded that they did not expects girls to be active participants. From this we can conclude that most female students lack confidence in their ability to participate in the classroom which indicates that there is low self-efficacy.

As it is indicated in item 8 of the above question, majority of i.e. 81 (67.5\%) of grade 9 female students replied that family occupation affect girls' participation in the school. On the contrary, 39 (32.5\%) of female students answered that family occupation does not affect female students' participation. This data shows that family occupation highly affects girls' participation in the school.

\begin{tabular}{|c|c|c|c|c|}
\hline No. & Item & Alternative & No of Respondents & In Percentage (\%) ) \\
\hline \multirow{2}{*}{1.} & \multirow{2}{*}{$\begin{array}{c}\text { Do you motivate female students' } \\
\text { participation in English class? }\end{array}$} & Yes & 14 & $77.8 \%$ \\
\cline { 3 - 5 } & & No & 4 & $22.2 \%$ \\
\cline { 3 - 5 } & & Total & 18 & $100 \%$ \\
\hline 2. & \multirow{2}{*}{\begin{tabular}{c} 
Do you have interest to ask \\
question female students in the \\
\cline { 3 - 5 }
\end{tabular}} & Yes & 16 & $88.9 \%$ \\
\cline { 3 - 5 } & classroom? & No & 2 & $11.1 \%$ \\
\cline { 3 - 5 } & & Total & 18 & $100 \%$ \\
\hline
\end{tabular}

Table 7: Teachers' Response on Motivating Female Students' Participation

As it is indicated in item number 1 above, 14 (77.8\%) of English teachers replied that they motivate female students' while 4 (22.2\%) of teacher respondents said that they do not motivate female students in their classroom. By comparing replies provided by teachers and students one can see that there is contradiction. Teachers believe that they are motivating female students to take part in the learning process although students do not think in the same way. This shows that students expect more from their teachers in order to take part actively in their classrooms.

As table 7 item number 2 indicates, large number of i.e. 16 (88.9\%) of English teachers said that they want to ask questions female students in the classroom. Only $2(11.1 \%)$ of the respondents said that they do not have interest to ask their female students while they teach English language. This shows that most of the teachers are interested to ask female students in the classroom. As the above table indicates, most English teachers motivate and have also interest to encourage female students in the classroom so as to increase their participation.

\begin{tabular}{|c|c|c|c|c|}
\hline No & Item & Alternative & No of respondents & In percentage (\%) ) \\
\hline 3. & Do you use different teaching & Yes & 12 & $66.7 \%$ \\
\cline { 3 - 5 } & $\begin{array}{c}\text { techniques to increase self- } \\
\text { confidence of female students? }\end{array}$ & No & 6 & $33.3 \%$ \\
\cline { 3 - 5 } & Total & 18 & $100 \%$ \\
\hline \multirow{2}{*}{4.} & \begin{tabular}{c} 
Do female students attend the class \\
and participate in English classroom \\
\cline { 3 - 5 }
\end{tabular} & Yes & 12 & $66.7 \%$ \\
\cline { 3 - 5 } & regularly? & No & 6 & $33.3 \%$ \\
\hline
\end{tabular}

Table 8: Teachers' Response on Females' Lack of Confidence and Attending Classes

As table 8 question number 3 indicates, $12(66.7 \%)$ of the teacher respondents said that they use different teaching techniques to increase self-confidence of their female students. On the contrary, half of the respondents i.e. 6 $(33.3 \%)$ of them said that they did not use different techniques to increase their female students' confidence. Hence, this shows that most teachers use different teaching techniques to increase their female students' self-confidence.

As table 8 of question number 4 also indicates, majority of the respondents i.e. 12 (66.7\%) of English teachers said that female students attend the class regularly and participate in their classroom. On the contrary half of them i.e. only 6 (33.3\%) of English teachers said that their female students did not attend the class and participate in their English language classrooms. This data reveals that there are some female students who did not attend and participate in English classrooms even though majority of them did.

\begin{tabular}{|c|c|c|c|c|}
\hline No. & Item & Alternative & No of respondents & In percentage (\%) \\
\hline \multirow[t]{3}{*}{5.} & \multirow{3}{*}{$\begin{array}{l}\text { Are there some expectations } \\
\text { from boys and afraid of being } \\
\text { criticized by other students in } \\
\text { your class? }\end{array}$} & Yes & 12 & $66.7 \%$ \\
\hline & & No & 6 & $33.3 \%$ \\
\hline & & Total & 18 & $100 \%$ \\
\hline
\end{tabular}

Table 9: Teachers' Response on Some Expectations of Female

Students from Boys and Afraid of Being Criticized by Others

In table 9 above, 12 (66.7\%) of English teachers replied that female students have expectation from boys and afraid of being criticized by other students. On the contrary, only 6 (33.3\%) of the respondents of English teachers said that female students have no expectation from boys and do not afraid of being criticized by other students in the classroom. From this, one can conclude that significant majority of girls have developed some kind of dependency which may lead them to be low performer on their male counterparts and afraid of being criticized by other student in the classroom. 


\section{Data Analysis of Observation}

In addition to that of questionnaire as a tool, the researcher also used observation where it was observed that lack of self-confidence made female students to have low participation in the classroom. When the researcher compared female and male students during group discussions, female students prefer male students as their leader in group discussions. This decreases the participation of female students and makes them to fear their classmates and their teachers as well. The researcher also observed that boys were dominating in participation and talking more in the group discussion activities than female students.

The other thing that was revealed during observation session was lack of reward. To increase female students' participation, teachers did not make significant effort in actual teaching learning process. This makes female students to be passive in the classroom and reluctant to participate in a given task. On top of that, teachers were not encouraging, good performance and well behaving students at least by using praising words.

\section{Conclusion and Recommendation}

\subsection{Conclusion}

On the bases of the findings of the study, the researcher has drawn the following conclusions:

The data identified that among the factors for female students' low participation; female students' attitude towards their education in the school enforces them to be passive participants. Their attitude toward themselves is not totally positive. The result from the data also shows that most of female students do not share their problems for their teachers clearly and they are not active participants in the classroom. According to the data that is revealed through questionnaire, family occupation is another factor for the low participation of female students. Here, family occupation has high relationship with students' participation in their classroom. The questionnaire also pointed out that the attitude of parents towards education of girls could highly influence the effective participation and general performance of female students. Based on the result, the parents are more interested to teach boys than girls. Finally, what was identified as female students' participation hindering factor is based on researcher's observation is lack of female students' encouragement. Encouraging, good performance and well behaving students through rewarding system are almost non-existent in Ambo secondary school.

\subsection{Recommendation}

Based on the above conclusions, the following commendations are forwarded:

- Female students should be encouraged to have better future as a result of their due attention for their education. They should have to have awareness beforehand.

- Female students should be motivated to share their feelings to their teachers that may be developed through group work discussions which are given by their respective teachers.

- The family of the learners in general and that of female students should have to work hard so that they can full fill basic learning materials for their children that may pave way of their future life.

- The attitude of parents towards female education should be changed through teaching learning process. Inequality of sex should also be removed from the mind of parents and female students should develop positive attitude towards their education.

- English teachers should use praising words in order to motivate female students so as to be active participants in their language classrooms. In conclusion, all stakeholders have responsibility in creating awareness about the importance of educating girls and giving constant support.

\section{References}

i. Asfaw\&Menna (1987). Female Participation and Performance in Rular school in Ethiopia. Addis Abeba: ICDR, MOE.

ii. Association for Development in Africa. (2005) Conference on bilingual education and the use of local languages in education. International Education Journal, 17 (2), 1-5.

iii. Berdine, R. (1986). Why some students fail to participate in class. Marketing News, 20 (15), 23-24.

iv. Constantinople, A., Cornelius, R, \& Gray, J. (1988). The chilly climate: Factor or artifact? Journal of Higher Education, 59(5), 527-550.

v. David, B. \&Marrew (2000). Secondary Teacher Education: Addis Abeba University press.

vi. Gall, M.D., and K.L. Acheson. 2011. Clinical supervision and teacher development: Pre service and in service applications. $6^{\text {th }}$ ed. Hoboken, NJ: John Wiley and Sons.

vii. Gardner. R, C. (2006). The Social-educational model of second language acquisition: A research paradigm. EUROSLA Yearbook,6(1), 237-260.

viii. Genet Z. (1998) Women in Education: A Study of Academic Performance and Participation: Addis Abeba region: AAU press, vol. 6 no 1.

ix. Liu, N.-F., Littlewood, W (2005). Why do many students appear reluctant to participate in classroom learning discourse System.

x. Malekela, G. (2003) English as a medium of instruction in prost-primary education in Tanzania: It is a fair policy to the learners'? In: Brock-Utne, B., Desai, Z., \& Qorro, M. (eds.). Language of instruction in Tanzania and South Africa. (LOITASA). Dar es Salaam: E\&D Limited.

xi. Purrelius, A. and Robert (1978). The Sociology of Education New Jersey: premice.

xii. R. Mishira (1985) Women Education a Research Approach: Ashia:Ashia publishing house 8118 punjabiBaghi. 
xiii. Roy-Campbell, Z.\& Qorro, M. (1997) Language crisis in Tanzania. Dar es Salaam: Mkuki na Nyota.

xiv. Tadesse Shiferaw (2009).Understanding Female Students' Academic Performance: An Exploration of the Situation in South Nations Nationalities and Peoples. The Hague, The Netherlands Available athttps:/ / www.google.com.et/ search?q=factors +affecting +female students[Accessed on6 January 2015]

xv. Woldu (1991). Factors that affect the Enrollment of High school students in Arsi zone, AAU

xvi. Vuzo, M. (2010) Exclusion through Language: A reflection on classroom discourse in Tanzanian Secondary Schools. Papers in Education and Development, 29, 14-36.

xvii. Wade, R.C.(1994). Teacher education students' views on class discussion: Implications for fostering critical reflection. Teaching and Teacher Education, 10 (2), 231-243.H.

xviii. Yavuzer, H. (2000). Okul cagi cocugu (school age child). Istanbul: Remzi.

xix. Yusuf, I (2007) Classroom Participation: A Case of a Junior High School Students in EFL Contextfile.upi.edu/ ... paper-CONAPLINE-participation-Fazri\%26Intan.pdf. 